\title{
RECOVERY OF SPIDER COMMUNITIES AFTER A SPONTANEOUS SUMMER FIRE IN THE FORB-BUNCHGRASS STEPPE OF EASTERN UKRAINE
}

\author{
Nina POLCHANINOVA*
}

\begin{abstract}
Recently, anthropogenic fires in protected areas have become more frequent. I studied the response of the spider community after an extensive summer fire in the 'Striltsivskyi Steppe' Reserve in eastern Ukraine. A total of 117 spider species was found in the pre-fire period, 40 species were registered in the first and 89 species in the third post-fire year. Herb-dwelling spiders began to colonize burnt plots in July, when juveniles of the new generation began dispersing. In September, their abundance was similar to that of undisturbed steppe and within three years, the spider assemblages recovered almost completely. Cursorial ground-dwellers in the first post-fire year decreased in species richness and increased in activity density. In the third year, their species diversity and activity density became much higher than in control plots. Some xerophilous species benefited from the fire. Litter dwellers are extremely vulnerable. During the three post-fire years, their numbers and diversity did not recover. Some rare species with a patchy geographical distribution disappeared from the local fauna. Such a reaction of endangered species is the main restriction on the use of fire as a conservation management. The prerequisite for its implementation is maintaining relevant refuges for threatened species. Keywords: endangered species, post-fire recovery, spider assemblage, 'Striltsivskyi Steppe' Reserve, summer fire.
\end{abstract}

\section{Izvleček}

Antropogeni požari na zavarovanih območjih so v zadnjem času vse bolj pogosti. Proučevala sem odziv združbe pajkov po ekstenzivnem poletnem požaru v rezervatu 'Striltsivskyi Steppe' v vzhodni Ukrajini. V obdobju pred požarom sem našla 117 vrst pajkov, 40 vrst je bilo zabeleženih v prvem letu, 89 vrst pa v tretjem letu po požaru. Pajki, ki prebivajo na zeliščih, so začeli naseljevati požgane ploskve julija, ko so se začeli razširjati juvenilni osebki nove generacije. Septembra je bila njihova abundanca podobna kot v nemoteni stepi in po treh letih se je vrstna sestava pajkov popolnoma obnovila. Vrstna pestrost pajkov, ki prebivajo na tleh, se je v prvem letu po požaru zmanjšala, povečala pa se je njihova aktivna gostota. V tretjem letu sta bili vrstna pestrost in aktivna gostota višji kot na kontrolnih ploskvah. Nekatere kserofilne vrste so imele zaradi požara prednost. Vrste, ki jih najdemo v opadu, so izredno ranljive. Njihovo število in pestrost se v treh letih po požaru nista obnovila. Nekatere redke vrste z zaplatasto geografsko razširjenostjo, so izginile s tega območja. Odziv redkih vrst je glavna omejitev za uporabo ognja za naravovarstven način gospodarjenja. Predpogoj za njegovo uporabo je vzpostavitev ustreznih zatočišč (refugijev) za ogrožene vrste.

Ključne vrste: ogrožene vrste, obnova po požaru, vrstna sestava pajkov, rezervat 'Striltsivskyi Steppe', poletni požar.

\section{INTRODUCTION}

Fire is considered to be a natural factor that plays a key role in the origin and evolution of dry grassland ecosystems (Osychnyuk \& Istomina 1970, Anderson 1990, Robertson et al. 1997, Tish- kov 2003). Periodical fires reduce the penetration of woody plants and encourage the development of forbs and grasses, which are resilient to fire. Traditionally, local people used fire against their enemies during wars and for hunting and pasture improvement during peacetime (Panzer

\footnotetext{
* Department of Zoology and Animal Ecology, Biological Faculty, V. N. Krazin Kharkiv National University, 4, Svobody Sq., 61072 Kharkiv, Ukraine, polchaninova@mail.ru
} 
2002, Vale 2002, Tishkov 2003, Gavrilenko 2007). Many scientists consider that in modern conditions, with a lack of wild herbivores, fire is the only way to prevent the excessive accumulation of plant material and maintain steppe vegetation in natural condition (Heidorn 1991, Lysenko 2008, Tkachenko 2009). Their opponents insist on the destabilizing role of fire for isolated steppe areas and the disappearance of rare species (Nemkov \& Sapiga 2010, Chibilev 2014).

In the tall-grass prairies of Northern America, prescribed burning is widely used as conservation and landscape management. Therefore, the impact of fire on local biota is well studied there (Warren et al. 1987, Anderson 1990, Rook et al. 2011). However, in the case of a variety of invertebrates, there still remain a lot of knowledge gaps (Anderson et al. 1989, Swengel 2001, Nekola 2002, Hartley et al. 2007). Short-grass prairies do not need so much burning, they are less combustible and fire events are rarer. Consequently, they attract the attention of scientists infrequently (Parmenter 2008).

In Eurasian steppes and steppe-like habitats, the aftermaths of fires are less studied. Recently, the interest of scientists and conservationists in this traditional method has increased (Ryabtsov 2005, Tkachenko et al. 2010, Valkó et al. 2013). Long-term studies are rather an exception (Kahmen et al. 2002, Page \& Goldammer 2004, Nemkov \& Sapiga 2010). Most published studies comprise one-two year investigations of selected taxa after anthropogenic local fires (Oparin \& Oparina 2003, Prishutova \& Arzanov 2008, Savchenko 2009, Samu et al. 2010). Long-term studies in Eurasian steppes are badly needed, because uncontrolled fires are becoming more and more frequent.

The post-fire recovery of the dry-grassland community depends on a confluence of many factors: geographical position, site area and topography, season, frequency and intensity of fire, meteorological conditions, adjacent habitats, vegetation structure and the life cycles of the organisms considered (Anderson 1990, Robertson et al. 1997, Swengel 2001). It is hardly surprising that the researchers of such a complicated matter come to contradictory conclusions.

Fire definitely affects various components of dry grassland biota in different ways. The response of invertebrates is not fully understood, it can be negative, positive or neutral (Guseva \& Bogach 1988, Swengel 2001, Nekola 2002, Panzer
2002, Prishutova \& Arzanov 2008, Savchenko 2009, Nemkov \& Sapiga 2010). My research is aimed at studying the short-term effects of anthropogenic summer fires on spider communities in the forb-bunchgrass steppe in eastern Ukraine.

\section{METHODS}

The 'Striltsivskyi Steppe' section of the Luhansk Nature Reserve is situated in the northeast of the Luhansk Area, Ukraine (49 $17^{\circ} \mathrm{N} 40^{\circ} 00^{\prime} \mathrm{E} 147 \mathrm{~m}$ a.s.l., Figure 1). It lies on the southern slopes of the Central Russian Upland in the north of the steppe natural zone, and represents a northern variant of the forb-Festuca-Stipa steppes. The reserve area is 1036 ha. Upper interfluves and gully slopes are covered with shrub steppes formed by Caragana frutex (L.) K.Koch, Amygdalus nana L. and Chamaecytisus ruthenicus Wol. The herb layer is dominated by turf grasses (Stipa tirsa Steven, S. zalesskii Wilensky S. pulcherrima K.Koch.) and rhizomatous grasses (Elytrigia intermedia (Host) Nevski, and Poa angustifolia L.). The long term succession on about a third of the reserve area has resulted in the formation of mixed 150-180 cm high shrub thickets with 50-90\% canopy density. A mowing regime has created shrub-steppe dominated by Caragana frutex, Stipa tirsa and a variety of forb species as co-dominants. Gully bottoms are covered with meadow vegetation (Tkachenko 2009).

During two recent decades, the reserve experienced three extensive fires, in 2003, 2007 and 2008. The latter took place on $25^{\text {th }}$ August and resulted in total burning of the reserve (980 ha) and adjacent gullies and fields (4,500 ha). The year 2008 was typical for the region, with a mild wet spring and autumn while the years 2009-2011 were extremely hot and dry (Borovyk 2012).

Initially, spiders were studied in 1984-1986 and 1999-2000, with the aim of conducting a faunal inventory of the 'Stiltsivskyi Steppe' Reserve. Spiders were collected by sweep-netting, pitfalltrapping, quadrat sampling and hand-collecting in various plots of the reserve: strictly protected steppe on the upper interfluves, gully slope and bottom, steppe under mowing regime at the same orographical position, and pasture in the steppe and dry meadow. Plastic cups of $6.5 \mathrm{~cm}$ diameter containing $4 \%$ formalin served as pitfall traps. Ten traps at intervals of $10 \mathrm{~m}$ were set in a transect on each plot for three days in May 1984, July 


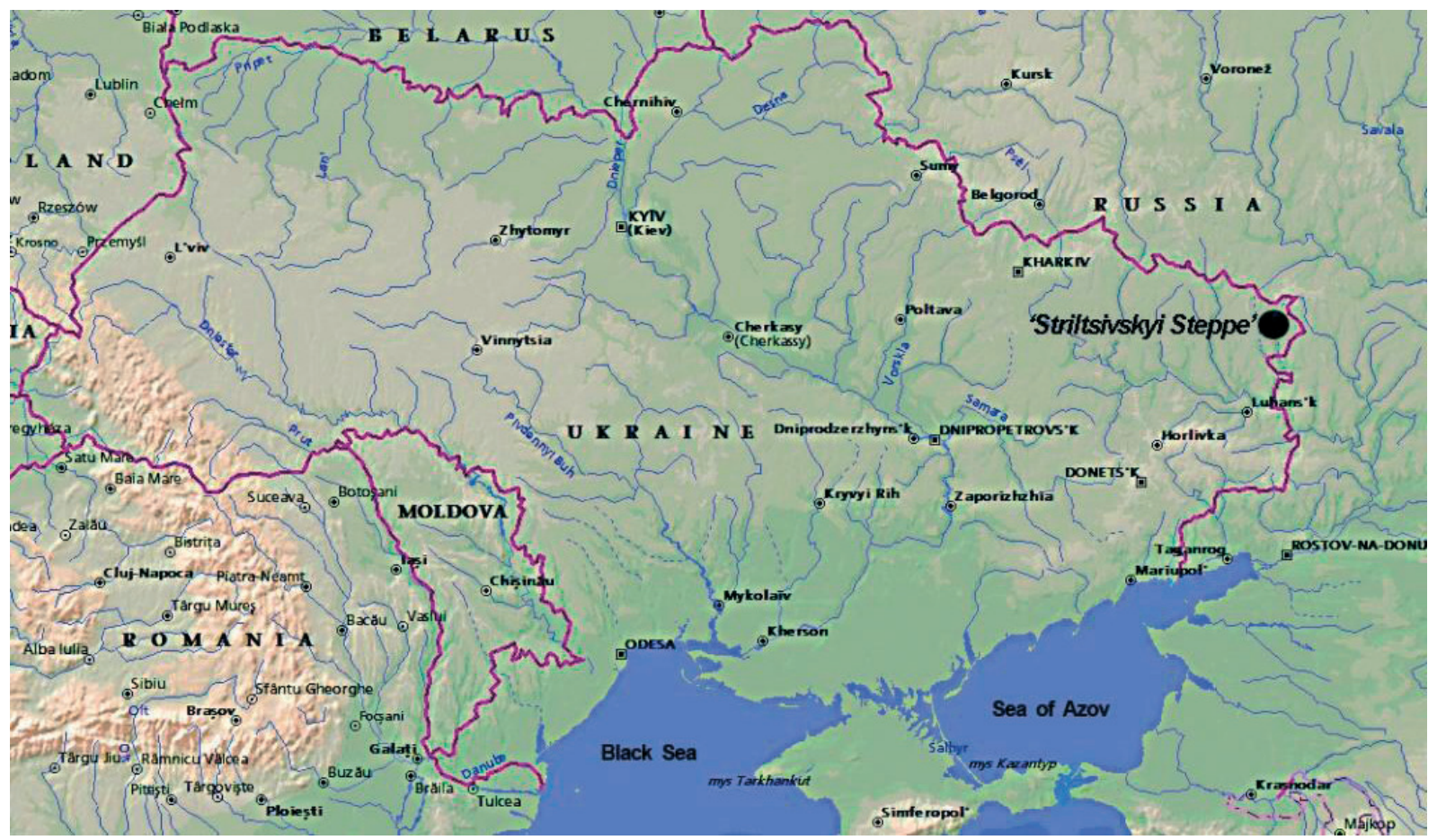

Figure 1: Locality of the 'Striltsivskyi Steppe’ Nature Reserve.

Slika 1: Lokacija naravnega rezervata 'Striltsivskyi Steppe'.

1985, May, June and July 1986. For the sweepnetting, I used $30-\mathrm{cm}$ diameter entomological net and made three-five samples of 25 double sweeps per plot. The samples were taken in the same period as the pitfall-trapping and also in September 1984, 1986. A quadrat sample was performed in May-July and September 1986, with hand collection on $1625 \times 25 \mathrm{~cm}$ sample plots on the ground and/or litter layer on the upper interfluves with and without mowing and in the gully bottom. In June 1999-2000, spiders were collected during 10 days from five transects of 10 pitfall traps in the strictly protected steppe and gullies (Prokopenko, pers. com.).

After the fire, the research was carried out in May-September 2009 and 2011, i.e. in the first and the third years after the fire. Five plots in the most representative parts of the reserve landscape and vegetation were chosen for quantitative sampling. As a control, I established three study plots in a gully $3 \mathrm{~km}$ from the reserve. Although the gully was deep and differed in slope exposition, it was the only adjacent location left intact by the fire. Its upper part could be compared with the upper interfluves, while its branch was similar to the shallow gullies in the reserve. The studied plots were as follows:
1. Strictly protected steppe on the upper interfluves (UpInt1) - thickets of $C$. frutex and $A$. nana with subdominant Prunus stepposa Kotov and Rhamnus cathartica L. and patchy turfgrass associations.

2. Mown steppe on the upper interfluves (UpInt2) - shrub-steppe formed by $C$. frutex with dominance of S. tirsa, S. zalesskii and subdominant steppe forb species.

3. Gently sloping deep gully of NW exposition (Slope) - shrub-steppe with dominance of $C$. frutex, A. nana, E. intermedia, B. inermis and $S$. tirsa.

4. Bottom of a shallow gully with a NW orientated mouth (Gully1) - steppe-meadow dominated by E. intermedia and Calamagrostis epigeios (L.) Roth, with subdominant meadow-steppe forbs (Fragaria viridis Duchesne, Filipendula vulgaris Moench) and turfgrasses ( $S$, tirsa, $S$, pennata L., Festuca rupicola Heuff.).

5. Bottom of a shallow gully with a NE orientated mouth (Gully2) - steppe-meadow dominated by Latella rossica Novopokr., Euphorbia semivillosa Prokh. and E. intermedia.

6. Upper part of the control gully (UpSlC) shrub-steppe with a dominance of $C$. frutex, $S$. tirsa, $S$. zalesskii and subdominant forb species 
7. Middle part of the control gully (MdSlC) shrub-steppe with a dominance of $C$. frutex and Bromopsis riparia.

8. Bottom of a shallow branch of the control gully (GullyC) - steppe-meadow dominated by E. intermedia and Fragaria viridis Duchesne.

The plots 1-4 coincided with the sampling plots of 1986. For a more complete spider fauna assessment, I also collected material in a pasture near the river and in a 25-year-old abandoned field on the upper interfluves, which are also part of the reserve. The data are included in the general list of species.

In the post-fire period, I used the same methods as in 1984-1986. Ten traps in a transect were set on 3-6 $6^{\text {th }}$ May 2009 and 2011 on each of the eight above described plots and emptied on $1-6^{\text {th }}$ June and $8-12^{\text {th }}$ July. As a result, 2151 spiders were collected, including 2024 adults. I conducted sweep-netting monthly during May-September 2009 and 2011, five samples of 25 double sweeps on the plots Nos. 1, 4, 6 and 8, were taken. This method gave 2978 specimens, including only 703 adults. Quadrat sampling was performed on the same dates as the sweep-netting on the plots 1 , 2, 3, 6 and 8. Only 173 spiders were obtained, of which 48 were adults. I censused the cursorial ground-dwelling spiders, herb-dwelling spiders and the less mobile litter/ground-dwelling spiders, respectively with these three methods. Their abundance and species diversity were estimated separately.

I used the same sampling methods in the pre- and post fire periods, only the quadrat sampling was performed with the same regularity in 1986, 2009 and 2011. Pitfall trap exposition and the number of sweep-net samples were different, that is why I do not compare quantitatively, but faunistically.

The alpha diversity of spider assemblages was assessed for species richness (Margalef index), species richness and distribution of individuals between the species (Shannon index), and average proportional abundance of the species (Simpson index: $1-D$ ). These indices are widely used in ecological studies (Magurran 1991).

In order to determine species relative abundance, I used the Tischler rating scale, with an additional rank for extremely numerous species (eudominant-1 $n \geq 20 \%$, eudominant- $10 \leq n<20 \%$, dominant $5 \leq n<10 \%$, subdominant $2.5 \leq n<5 \%$, recedent $1 \leq n<2.5 \%$, and subrecedent $n<1 \%$
Tischler 1949). I considered eudominants and dominants together as a dominant complex. For the most common herb dwellers, it was possible to identify juvenile individuals to the species level, as they represented the only species in their genera or had a remarkable appearance or varied in maturation time. In the other cases, I identified the specimens to genus level, such as Xysticus spp. juv., Evarcha spp. juv., etc. Juvenile ground-dwellers could not be identified to the species level, so the data comprises adult individuals only. However, in quantitative analysis, the activity density of cursorial spiders was estimated as number of both juvenile and adult individuals/100 trap-days. Species ecological characteristics are based on data on their habitat preferences within the forest-steppe and steppe zones of the East European Plain (Pichka 1984, Ponomarev \& Tsvetkov 2004, Ponomarev \& Polchaninova 2006, Polchaninova \& Prokopenko 2013).

Data analysis was performed using the program Statistica 7. I used whiskered boxes and whiskered graphs to analyze seasonal and annual dynamics of the herb-dwelling spiders. I used Ward's method as a cluster algorithm and Euclidian distance as similarity measure when preparing a dendrogram of the dominant complexes biocenotic similarity. Comparison of grounddwelling spider assemblages was made using an ANOVA procedure. The material from ten traps per plot was pooled into one plot sample. Then these samples were grouped per year and per burnt or unburnt site in each year. I applied univariate analysis using type of pairwise comparison as a grouping factor and differences in species relative abundance as a dependent variable.

I did not perform statistical analysis of the less mobile litter-dwelling spider assemblages because of the low numbers of adult individuals.

\section{RESULTS}

\subsection{Species Composition}

A total of 117 spider species from 22 families was recorded from the 'Striltivskyi Steppe' Reserve during the pre-fire period (Prokopenko 2001a, $2001 b$, personal data). Of these, Salticidae, Lycosidae, Gnaphosidae and Thomisidae were the most species rich (Figure 2, Appendix). The total species richness was comparable with that of the other nearest steppe reserves, situated north- 


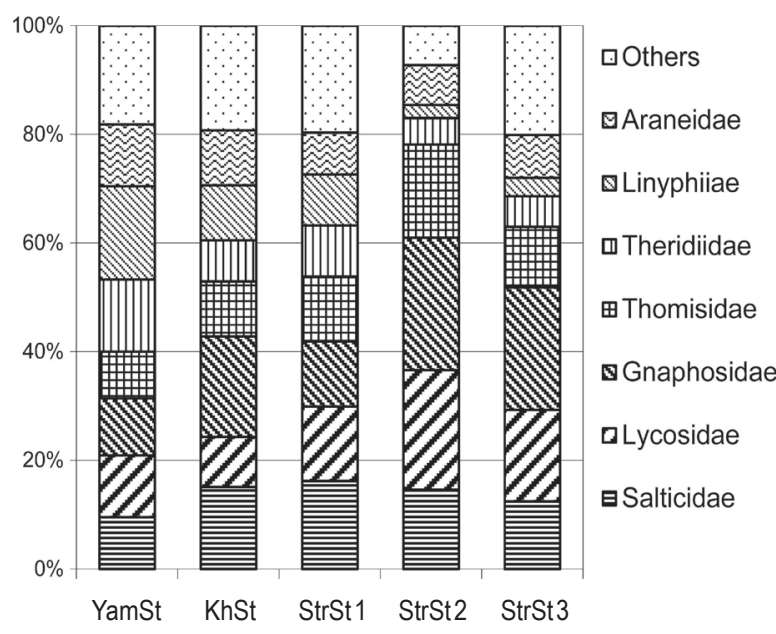

Figure 2: Relative species richness of spider families (\%) in the faunas of three steppe reserves YaSt - Yamskaya Steppe (after Polchaninova, 2002), KhSt - Khomutivskyi Steppe (after Polchaninova, 2006), StrSt - Striltsivskyi Steppe. StrSt 1 - before the fire, StrSt 2 - first post-fire year (2009), StrSt 3 - third post-fire year (2011).

Slika 2: Relativna vrstna pestrost družin pajkov (\%) v favni treh stepskih rezervatov YaSt - Yamskaya stepa (po Polchaninova, 2002), KhSt - Khomutivskyi stepa (po Polchaninova, 2006), StrSt - Striltsivskyi stepa. StrSt 1 - pred požarom, StrSt 2 - prvo leto po požaru (2009), StrSt 3 - tretje leto po požaru (2011).

wards (Yamskaya Steppe) and southwards (Khomutivskyi Steppe) of my study site. One hundred and four species from 17 families were recorded from the 'Yamskaya Steppe', a southern variant of the meadow steppes (Polchaninova 2002, 2003), and 120 species from 20 families from the 'Khomutivskyi Steppe', a southern variant of the forb-bunchgrass steppes (Polchaninova 2006). However the species richness of the families was different (Figure 2), Linyphiidae and Theridiidae were best represented in the 'Yamskaya Steppe', while Gnaphosidae dominated in the 'Khomutivskyi Steppe'. Salticidae and Thomisidae both preferred forb-bunchgrass steppe, while the Lycosidae were more numerous in the meadow steppe and the northern forb-bunchgrass steppe. Other less numerous families comprised altogether $18.2-19.7 \%$ of the local faunas.

Before the fire in the 'Striltsivskyi Steppe', 52 species were recorded from the herb layer and 69 species from the litter/ground layer (some species inhabited both). In the first year after the fire, spider species composition declined to only 40 species of 10 families (Appendix). Gnaphosidae, Lycosidae and Thomisidae increased in relative richness, while the other families decreased (Figure 2).
Nearly all the species were recorded from pitfalls, with the exception of nine species found from the herb layer (I consider here adult individuals only). Two years later, the species composition recovered to 89 species from 18 families. Of these, 35 species occupied the herb layer, and 63 species occupied the ground/litter layer. The family Gnaphosidae remained the richest one, and was more speciose than before the fire, however the other families, except Philodromidae and Liocranidae, did not return to their pre-fire richness (Appendix).

In the control gully, 96 species from 19 families were recorded: 77 species in 2009 and 71 species in 2011 (Appendix). In both years, Gnaphosidae and Lycosidae were the most species rich, being more abundant in 2011. Salticidae richness in 2011, on the contrary, unexpectedly decreased. Other families did not show remarkable differences.

\subsection{Assemblages of Herb-Dwelling SPIDERS}

In May 2009, the grass layer was virtually empty. I recorded only two adult specimens of Tmarus piger and Xysticus ulmi by hand-collection and not a single individual by sweep-netting. Spiders gradually re-colonized the herbage, some juvenile Xysticus and Evarcha appeared in June, when a new generation of dispersing juveniles occupied vacant territory, and in September became as numerous as at the top of the control gully (Figure 3). These belonged to the typical dry grassland species, which mature and reproduce in late April (Agalenatea redii) or late May-June (Xysticus cristatus, Mangora acalypha, Neoscona adianta, Dictyna arundinacea, Tibellus oblongus, Heliophanus flavipes), the juveniles of which hatch in late July or August and constitute the majority of autumnal araneocomplexes. Xysticis striatipes has a contrasting life cycle. Its juveniles hatch in June and they are the first to settle new territories. During the first postfire year, this was the only species abundant in the mature stage. In the third year, the seasonal dynamics of spider abundance was similar to that on the unburnt plots: lower numbers in May, but still some 5-15 specimens, and maximum in July or August (Figure 3). Mean numbers of spider individuals rose and reached the abundance levels of the unburnt plots. The comparison of September samplings showed a statistically significant difference $(p<0.05)$ of spider abundance on the burnt plots in 2009 only (Figure 4). 

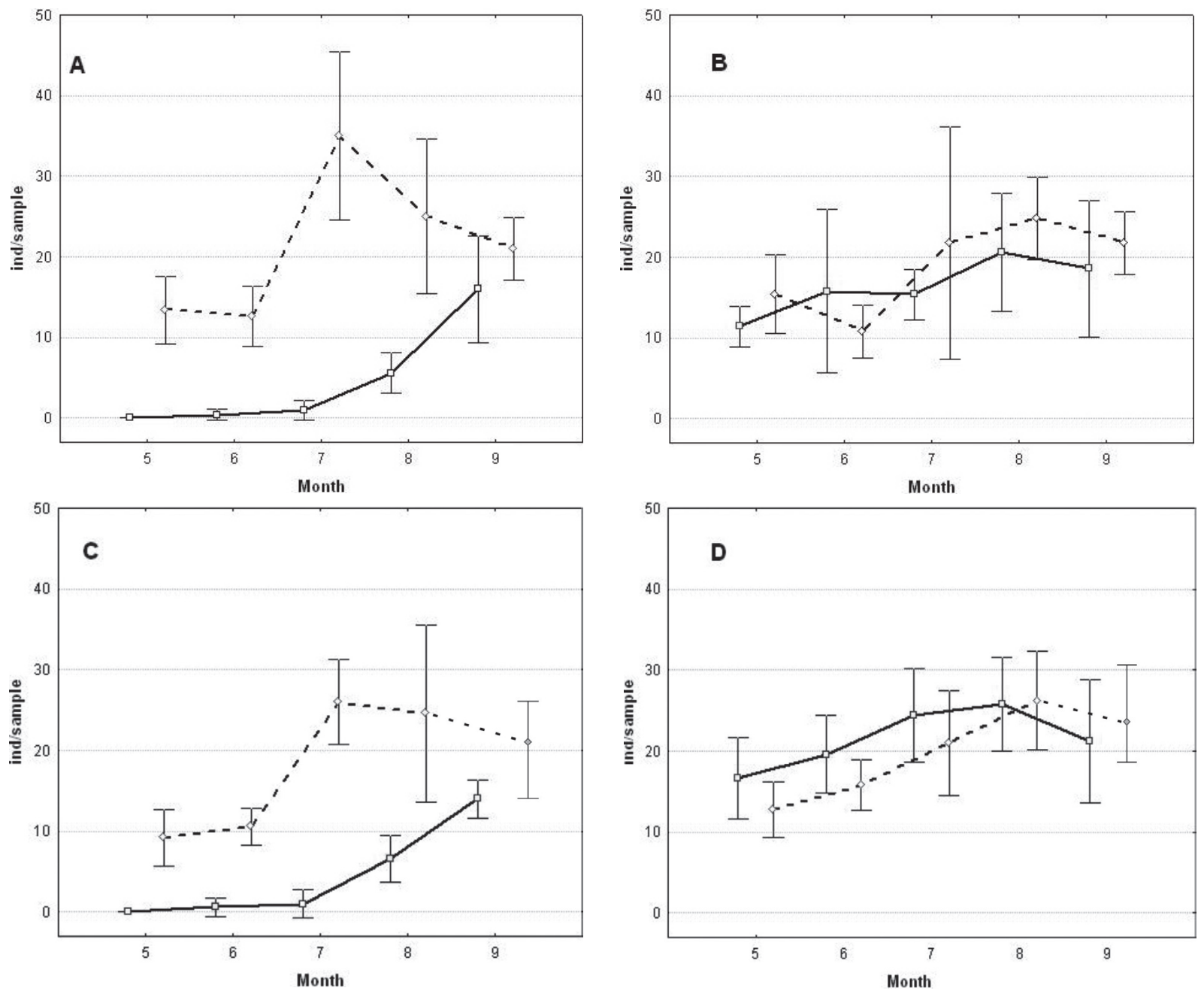

Figure 3: Seasonal dynamics of spider abundance in the herb layer. Solid line - 2009, dashed line - 2011, burnt (a) and unburnt (b) upper interfluves, burnt (c) and unburnt (d) gully bottom. Whiskers indicate the confidence interval.

Slika 3: Sezonska dinamika razširjenosti pajkov v zeliščni plasti. Neprekinjena črta - 2009, prekinjena črta - 2011, požgano (a) in nepožgano (b) na zgornjem grebenu med dvema rečnima dolinama, požgano (c) in nepožgano (d) dno jarka. Brki nakazujejo interval zaupanja.

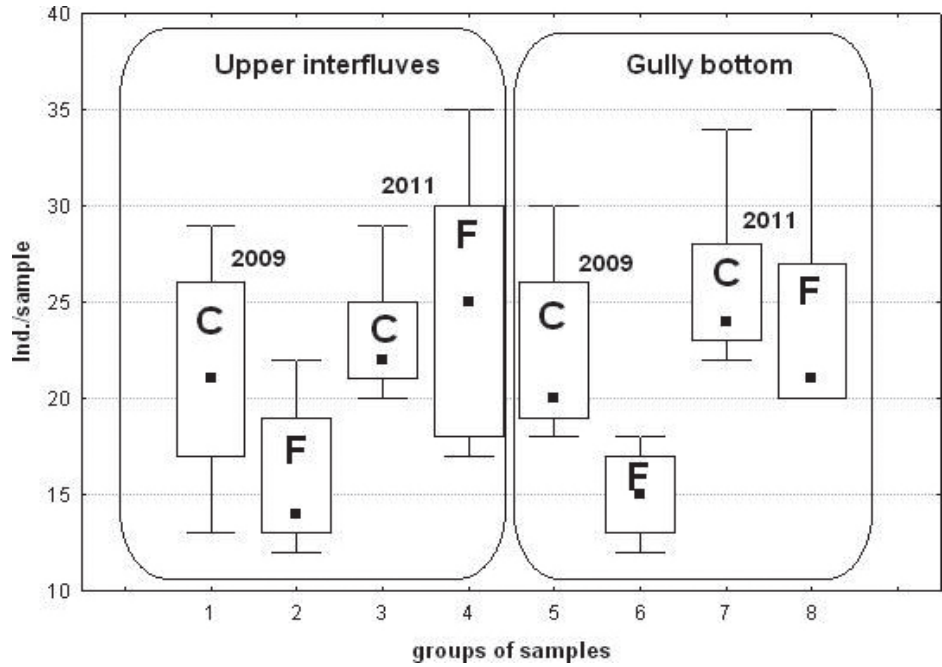

Figure 4: Spider abundance in September 2009, 2011 in the herb layer of burnt (F) and unburnt (C) plots. Whiskers indicate the minimum and maximum values.

Slika 4: Abundanca pajkov septembra 2009, 2001 $\mathrm{v}$ zeliščni plasti na požganih (F) in nepožganih ploskvah (C). Brki nakazujejo največje in najmanjše vrednosti. 
The species composition of the herb dwellers at the fire site grew from nine species in 2009 to 35 in 2011, being more or less stable in the control gully (33 and 29, respectively). In 2009 , juvenile Xysticus made up $30-39 \%$ of the spiders on the burnt plots, while in the unburnt gully it did not exceed 14\%. In 2011, the relative abundance Xysticus on different plots varied insignificantly, from 13.3 to $17.7 \%$. Mangora acalypha and Agalenatea redii were the second and third most numerous species. They dominated nearly all the studied plots in both years (Table 1). Argiope bruennichi was abundant in the gullies, but not in the first post-fire year, Tibellus oblongus was not included in the dominant complexes of the post-fire upper interfluves. The other species were periodical dominants on one or two plots in different years. All the dominant species are widely distributed and inhabit dry or mesic dry grasslands in Europe (Krasnobayev 2003, Horvath et al. 2009, Polchaninova 2012). However, X. striatipes is more abundant in drier habitats in the forb-bunchgrass steppe subzone, Dictyna arundinacea and T. oblongus prefer meadow-steppes, and A. bruennichi favours relief depressions. It should be noted that the general ratio of rare to common species in the first post-fire year on the burnt plots was much lower than that on the unburnt ones. The ratio comprised respectively $14 \%$ vs. $45.5 \%$ on the upper interfluves and $18.7 \%$ vs. $43.4 \%$ in the gully bottom. In the third year, the ratio of non-dominant species on the burnt plots increased to $29.4 \%$ vs. $47.2 \%$ on the upper interfluves and to $33.1 \%$ vs. $42.4 \%$ in the gully bottom.

A dendrogram of biocenotic similarity showed that dominant spider complexes on the unburnt plots were grouped depending on the orographical position (two pairs 'upper interfluves 2009-2011' and 'gully bottom 2009-2011'). At the fire site, on the contrary, the grouping factor was the post-fire period (Figure 5). Burnt plots 2011 joined the cluster of the unburnt ones.

Table 1: Dominant species of herb-dwelling spiders on the burnt (F) and unburnt (C) sites in 2009, 2011 (empty squares - the species was absent or did not reach the dominant status).

Tabela 1: Dominantne vrste pajkov, ki prebivajo na zeliščih na požganih (F) in nepožganih (C) rastiščih v letih 2009 in 2011 (prazni kvadrati - vrsta je bila odsotna ali ni dosegla statusa dominantne vrste).

\begin{tabular}{|c|c|c|c|c|c|c|c|c|}
\hline \multirow{3}{*}{ Species } & \multicolumn{4}{|c|}{ Upper interfluves } & \multicolumn{4}{|c|}{ Gully bottom } \\
\hline & \multicolumn{2}{|c|}{2009} & \multicolumn{2}{|c|}{2011} & \multicolumn{2}{|c|}{2009} & \multicolumn{2}{|c|}{2011} \\
\hline & $\mathrm{F}$ & $\mathrm{C}$ & $\mathrm{F}$ & $\mathrm{C}$ & $\mathrm{F}$ & $\mathrm{C}$ & $\mathrm{F}$ & $\mathrm{C}$ \\
\hline Xysticus spp. juv. & 0 & - & - & $\bullet$ & O & $\bullet$ & $\bullet$ & $\bullet$ \\
\hline Mangora acalypha & - & ○ & $\bullet$ & $\bullet$ & $\bullet$ & $\bullet$ & $\bullet$ & \\
\hline Agalenatea redii & - & $\bullet$ & ○ & O & & & $\bullet$ & $\bullet$ \\
\hline Tibellus oblongus & & - & & $\bullet$ & $\bullet$ & $\bullet$ & $\bullet$ & $\bullet$ \\
\hline Evarcha spp. juv. & & & & & $\bullet$ & $\bullet$ & & $\bullet$ \\
\hline Argiope bruennichi & & & & & & $\bullet$ & $\bullet$ & $\bullet$ \\
\hline Araneidae spp. juv & $\bullet$ & $\bullet$ & & & & & & \\
\hline Xysticus striatipes & $\bullet$ & & & & $\bullet$ & & & \\
\hline Cheiracanthium spp. juv. & $\bullet$ & & & & & & $\bullet$ & \\
\hline Dictyna arundinacea & & & $\bullet$ & & & & $\bullet$ & \\
\hline Philodromus cespitum & & & $\bullet$ & & & & & $\bullet$ \\
\hline Ebrechtella tricuspidata & & & & & $\bullet$ & & & \\
\hline Thomisus onutus & & & & & $\bullet$ & & & \\
\hline Araneus quadratus & & & & & & $\bullet$ & & \\
\hline
\end{tabular}

- eudominant-1 $n \geq 20 \%$, - eudominant-2 $10 \leq \mathrm{n}<20 \%$, •-dominant, $5 \leq \mathrm{n}<10 \%$ 


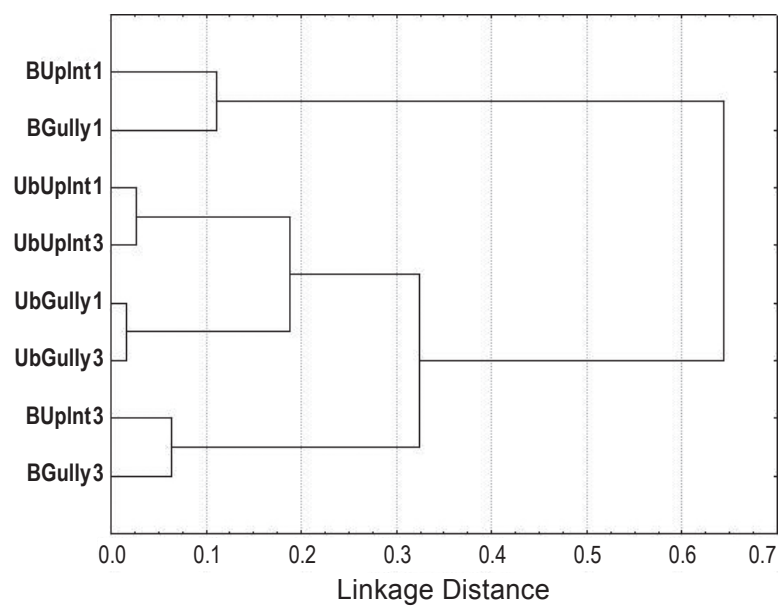

Figure 5: Dendrogram of biocenotic similarity of the dominant complexes of herb-dwelling spiders based on the percentage of each species in the samples on the burnt and unburnt plots in 2009 and 2011 using Ward's method as a cluster algorithm and Euclidian distance as similarity measure. For abbreviations see Material and methods.

Slika 5: Dendrogram biocenotske podobnosti dominantnih kompleksov pajkov, ki jih najdemo na zeliščih na podlagi odstotka vsake vrste $\mathrm{v}$ vzorcih na požganih in nepožganih ploskvah v letih 2009 in 2011 z Wardovo metodo kopičenja in Evklidsko razdaljo kot mero podobnosti. Za okrajšave glej poglavje Metode.

\subsection{Assemblages of Ground-Dwelling SPIDERS}

In the first post-fire year, cursorial spiders occurred at the burnt site from early spring and in May reached a total of 15-27 individuals/100 trapdays on the upper interfluves and 53-55 individuals in the gullies. Later in the summer, spider activity density usually declines (Polchaninova 2003, Prokopenko \& Savchenko 2013). In the reserve, activity density decreased by half in the gullies (24-25 individuals/100 trap-days), remaining at the same level on the upper interfluves (13-23 individuals/100 trap-days). Two spider families were the most species rich (Lycosidae - nine species, Gnaphosidae - 11 species), which is typical for pitfall-trapping in steppe habitats. In terms of individual activity density, lycosids made up $65.4 \%$ and gnaphosids $26.4 \%$ of the collected spiders. The dominant complex comprised six species, five of which belonged to the Lycosidae family. Trochosa terricola made up $27.7 \%$ of the collected specimens (Figure 6). It is a generalist species distributed widely in the forest-steppe and steppe zones but avoiding extremely dry conditions. In my material, it was followed by Alopecosa pulveru-

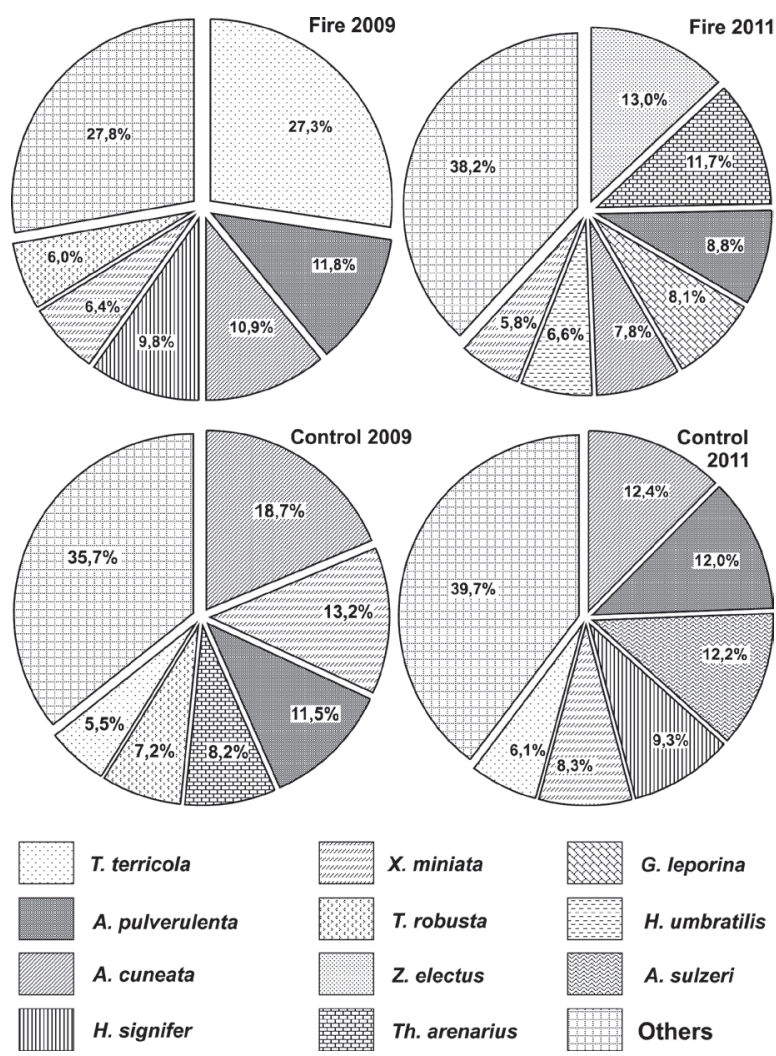

Figure 6: Dominant complexes of cursorial spiders at the burnt and unburnt sites in 2009 and 2011.

Slika 6: Dominantni kompleksi talnih pajkov na požganih in nepožganih ploskvah leta 2009 in 2011.

lenra, A. cuneata and Haplodrassus signifier, which can be characterized as mesophilous species of grasslands and open forests. Their relative activity density was less than half of that of the main dominant species. Xerolycosa miniata and T. robusta completed the dominant complex. They can be characterized as inhabitants of moderately dry grasslands, the former is often numerous in disturbed habitats. The other 25 species were less abundant and together constituted $27.3 \%$ of the catch.

In the third post-fire year, the species composition of cursorial spiders rose significantly on each studied plot, except the mown upper interfluves (Table 2). Activity density also increased on the upper interfluves and in the $1^{\text {st }}$ gully bottom, while in the $2^{\text {nd }}$ gully and on the slope it did not changed markedly. During this year, 63 species were caught, of which seven species constituted a dominant complex. The composition changed dramatically: it included three Lycosidae, three Gnaphosidae and one Philodromidae species, there was no main eudominant species and the species ratio declined gradually, the ratio of less 
Table 2: Alpha diversity of cursorial spider assemblages in different habitats of the 'Striltsivskyi Steppe' Reserve in the post-fire period $(2009,2011)$. For abbreviations, see Methods section.

Tabela 2: Alfa diverziteta sestave združb pajkov, ki prebivajo na tleh v različnih habitatih v rezervatu 'Striltsivskyi Steppe' v obdobju po požaru $(2009,2011)$. Za okrajšave glej poglavje Metode.

\begin{tabular}{|c|c|c|c|c|c|c|c|c|c|c|}
\hline \multirow{3}{*}{ Index } & \multicolumn{10}{|c|}{ Habitats } \\
\hline & \multicolumn{2}{|c|}{ UpInt1 } & \multicolumn{2}{|c|}{ UpInt 2} & \multicolumn{2}{|c|}{ Slope } & \multicolumn{2}{|c|}{ Gully 1} & \multicolumn{2}{|c|}{ Gully 2} \\
\hline & 2009 & 2011 & 2009 & 2011 & 2009 & 2011 & 2009 & 2011 & 2009 & 2011 \\
\hline Shannon & 2.06 & 2.45 & 2.14 & 2.51 & 2.58 & 2.65 & 2.19 & 2.75 & 1.97 & 2.69 \\
\hline Simpson $(1-D)$ & 0.83 & 0,85 & 0.80 & 0.89 & 0.90 & 0.89 & 0.84 & 0.90 & 0.79 & 0.90 \\
\hline Margalef & 2.89 & 4.85 & 3.64 & 3.97 & 4.20 & 5.67 & 3.97 & 5.86 & 2.73 & 5.77 \\
\hline Species richness & 12 & 27 & 17 & 23 & 22 & 32 & 17 & 36 & 11 & 32 \\
\hline Activity density (ind./100 trap-days) & 26.3 & 40.2 & 15.4 & 25.8 & 40.6 & 43.8 & 39.5 & 74.3 & 41.5 & 43.6 \\
\hline
\end{tabular}

abundant species rose to $38.3 \%$ (Figure 6). Among the seven dominants, four species were typical of moderately dry grasslands, two species of mesic grasslands, and one species that preferred dry forests. Three species remained from the previous complex, T. terricola, which was the most numerous in 2009, reached not more than the status of subdominant. The ratio of gnaphosids and lycosids changed radically, the former constituted $41.3 \%$ and the latter $27.3 \%$ of the catch.

In the control gully in both 2009 and 2011, the dominant complexes comprised of six species with $A$. cuneata as the first dominant and $\mathcal{T}$. terricola as the least dominant (Figure 6). The gully was dominated by the same species as the burnt reserve with the exception of Alopecosa sulzeri, which appeared in 2011. In both years, five species out of six belonged to the family Lycosidae. The hierarchical structure of the spider complexes was similar to that on the fire site in 2011 and was characterized by the lack of a single eudominant and a higher ratio of subdominantsubrecedent species. The number of species and individuals did not change significantly by years or by plots (Table 3).
The alpha diversity of cursorial spiders increased from the first to the third post-fire year. The Shannon index was higher for all the five spider complexes on the burnt plots (Table 2), however, on the slope, the difference was not statistically significant $(p<0.05)$. The Simpson index changed slightly on the slope and unmown upper interfluves, being significantly higher on the other three plots. The Margalef index increased markedly on the four plots (maximally from 2.73 to 5.57 in the $2^{\text {nd }}$ gully bottom) and remained almost unchanged on the unmown upper interfluves (3.64-3.97). In the control gully in 2011, the indices were in two cases higher, and in one case lower, than in 2009 (Table 3), and statistically significant differences $(p<0.05)$ were only recorded for the top of the slope. So, there was no clear trend in spider diversity on the undisturbed plots over the two study years.

In the pre-fire period, spider species composition depended on the relief and mowing regime. It was richer in the unmown gully and poorer on the upper interfluves, especially on the mown plots (Polchaninova 1990, 1995, Prokopenko $2001 \mathrm{~b})$. In the first post-fire year, species

Table 3: Alpha diversity of cursorial spider assemblages in different habitats of the control unburnt gully in 2009, 2011. For abbreviations see Methods section.

Tabela 3: Alfa diverziteta sestave talnih pajkov v različnih habitatih v kontrolirano požganem jarku v letih 2009 in 2011. Za okrajšave glej poglavje Metode.

\begin{tabular}{lcccccc}
\hline \multicolumn{1}{c}{ Index } & \multicolumn{2}{c}{ UpSl C } & \multicolumn{2}{c}{ H a Mitat s } & \multicolumn{2}{c}{ Gully C } \\
& 2009 & 2011 & 2009 & 2011 & 2009 & 2011 \\
\hline Shannon & 2.03 & 2.62 & 2.39 & 2.42 & 2.83 & 2.71 \\
Simpson $(1-D)$ & 0.80 & 0.90 & 0.83 & 0.86 & 0.86 & 0.81 \\
Margalef & 4.06 & 5.06 & 4.43 & 4.56 & 4.20 & 4.85 \\
Number of species & 21 & 22 & 18 & 22 & 25 & 27 \\
Activity density (ind./100 trap-days) & 18.8 & 20.3 & 25.1 & 21.4 & 20.8 & 22.7 \\
\hline
\end{tabular}




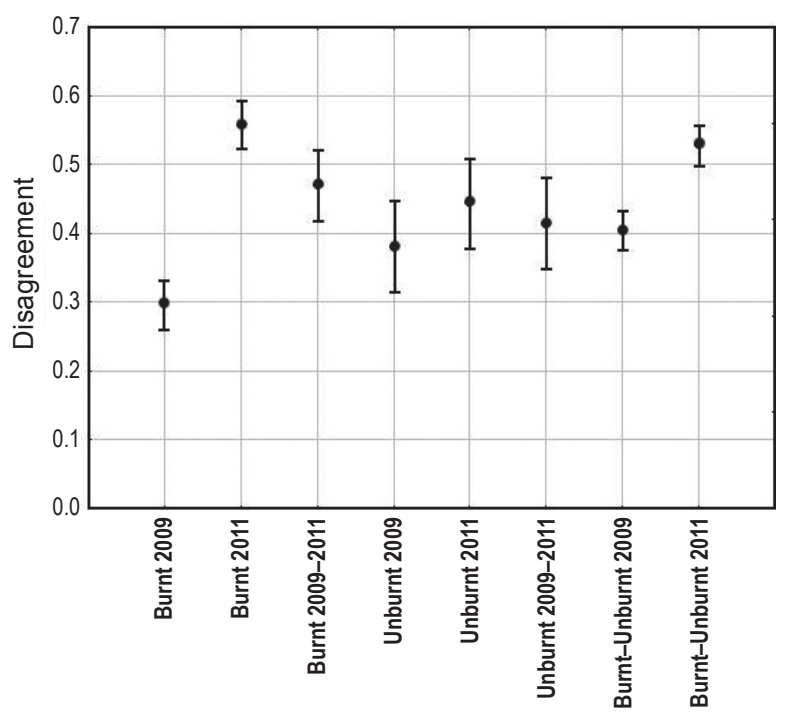

Figure 7: Differences between cursorial spider assemblages formed on the burnt and unburnt plots in different years. Whiskers indicate the confidence interval

Slika 7: Razlike med sestavo talnih vrst pajkov na požganih in nepožganih ploskvah v različnih letih. Brki nakazujejo interval zaupanja.

richness was constantly low across all the studied plots while activity density was higher in the gullies (Table 3). The lowest difference between spider assemblages (30\%) was recorded for the plots at the fire site in 2009 (Figure 7). The maximal difference was recorded at the same site in 2011 (55\%). In the unburnt gully, the disagreement between spider complexes by plots and/or years constituted $39-44 \%$. Spider assemblages of the burnt vs. unburnt sites were also very different in 2011 than in 2009.

I found no species, which had been attracted to the fire site and then left it within a three year period. However some species, such as the above mentioned Trochosa terricola, noticeably reduced in their numbers. On the contrary, eleven species increased in individual activity density or appeared on the burnt plots exactly in the third post-fire year (Alopecosa taeniopus, Arctosa maculata, Drassodes pubescens, Drassyllus praeficus, D. pusillus, Gnaphosa leporina, Haplodrassus kulzcynskuu, Zelotes electus, Thanatus arenarius, Ozyptila scabriucula and Aelurillus v-insignitus).

Before the fire, less mobile litter-dwelling spiders were also more abundant in the gullies than on the upper interfluves (Polchaninova 1990, 1995). I found 31 species by hand-collection from the litter and the quadrat samples. After the fire, their numbers dropped dramatically and in 2011

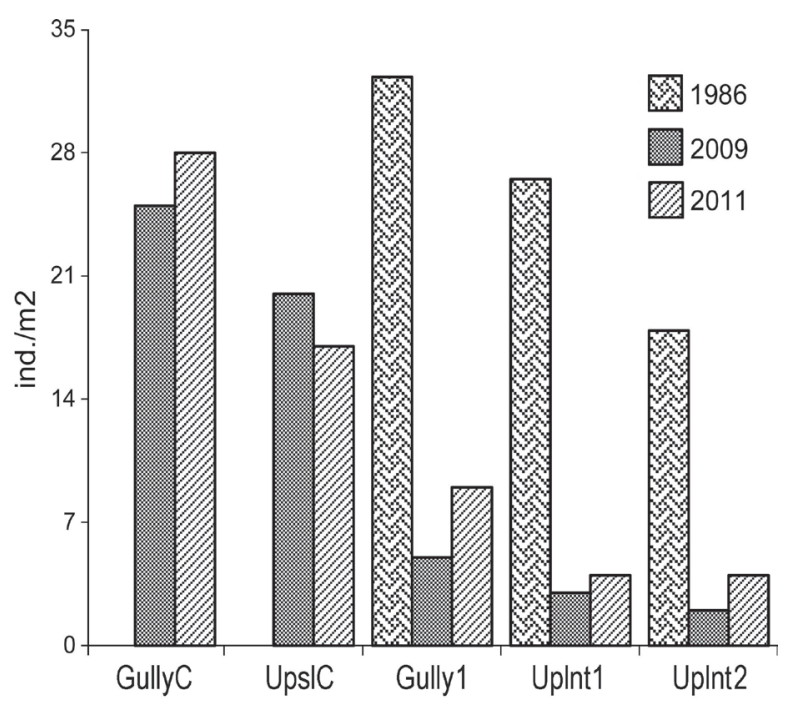

Figure 8: Densities of the litter-dwelling spiders in different habitats before and after the fire 2008. For abbreviations see Methods section.

Slika 8: Gostota pajkov, ki prebivajo v opadu v različnih habitatih, pred in po požaru leta 2008. Za okrajšave glej poglavje Metode.

remained three to five times lower than in the pre-fire period (Figure 8). During the post-fire years, I found only seven mature individuals of five species (Stemonyphantes lineatus, Thrichoncus vasconicus, Cercidia prominens, Agroeca cuprea, Haplodrassus kulczynskii), and the remainder were juveniles of Lycosidae, Gnaphosidae and Linyphiiae. In the control gully, spider density was lower during the post-fire period than in the reserve prior to the fire (Polchaninova, 1995) (Figure 8). Nevertheless, I found 24 species there that were not all numerous, represented by one to three individuals each.

\section{DISCUSSION}

Extensive fires during the period of plant and animal activity cause direct damage to invertebrates through the high mortality and indirect influences through environmental changes (Swengel 2001, Gavrilenko 2007). Very often such fires do not leave undisturbed refuges in the vicinity and recovery of invertebrate communities depends to a great extent on species ability to re-colonize sites (Warren et al. 1987, Nemkov \& Sapiga 2010).

In total, 40 species were not recorded after the fire in the 'Striltsivskyi Steppe', while 15 species appeared on the reserve territory. Thirty six spe- 
cies were recorded as singletons, which does not allow analysing their habitat preferences. Among the disappeared species, 11 (Crustulina guttata, Neottiura suaveolens, Theridion innocuum, Dactylopistes mirifica, Phrurolithus pullatus, Xysticus acerbus, Talavera aequipes, Simithidion simile, Agyneta rurestris, A. simplicitarsis and Minicia caspiana,) were common or numerous in the reserve in the pre-fire period. After the fire, the latter four were found in the control gully but not at the fire site. All of them, except $X$. acerbus, S. simile and Th. innoccuum, are litter-dependent. Eight newcomers (Agroeca maculata, Berlandina cinerea, Gnaphosa taurica, G. licenti, Haplodrassus kulzcynskii, Zelotes pseudogallicus, Aelurilus laniger, A. v-insignitus) can be characterized as xerophilous species, and they preferred plots with sparse vegetation. An increase in thermophilous and open habitat species at the fire sites has been reported for many invertebrate groups (Panzer 2002, Page \& Goldammer 2004, Bischof 2006, Nemkov \& Sapiga 2010, Prokopenko \& Savchenko 2013).

In general, spiders can be regarded as good dispersers, as they settle new areas by running fast or spreading by air. Smaller species balloon in both juvenile and adult stages, though it is mainly juveniles that disperse in such a way (Weyman 1993). With a few exceptions, herbdwellers are not good runners. As can be seen from my data, they began re-colonizing the postfire area only in July, with the appearance of ballooning juveniles. Consequently the majority of spiders collected during the first post-fire year were juveniles. During the third year after the fire, the species composition and abundance recovered almost completely and reached the level of the undisturbed community in the control gully. Despite the general similarity of undisturbed and recovered herb-dwelling spider assemblages, the difference in hierarchical structure still persisted even in the third year after the fire, when dominant species constituted a larger proportion of the community than on the control plots.

Cursorial spiders do not depend on the litter density, nor do they need grass for e.g. web building. Therefore they quickly re-colonize new sites, though they are sensitive to vegetation changes and the consequent impacts on microclimate conditions and availability of potential prey and shelter (Ysnel \& Canard 2000, Cobbold \& MacMahon 2012). The pioneer species are opportunists which are ecologically flexible and can colonize vacant niches quickly. In my study, this applies primarily to lycosid species, which were dominants in the first post-fire year. Although gnaphosids are considered to be xerophilous and thermophilous species, they were less abundant on the newly burnt plots and colonized these two or three years later. Moreover, in the third post-fire year they became more abundant than lycosids, which is not typical of the forb-bunchgrass steppes. Gnaphosidae species richness increased in comparison with the pre-fire years, and reached the level of family diversity in the southern forb-bunchgrass steppes (Khomutivskyi Steppe Reserve; Polchaninova 2006).

In my case, the first reaction of cursorial spider assemblages to extensive summer fires was a decrease in species richness and an increase in activity density. The latter can be explained not only by higher abundance but also by higher activity of spiders. On bare soil, invertebrates do not have shelter and need to move fast in search of prey, consequently, they are likely to be more prone to pitfall-trapping (Nemkov \& Sapiga 2010). Prescribed spring burning of a small plot in southern forb-bunchgrass steppe resulted in a significant increase in species richness and a small decrease in activity density. During the second year after the fire, spider abundance remained lower than at the control sites, while differences in species richness disappeared (Prokopenko \& Savchenko 2013). In the case of a wild spring fire in a small area of the dry bunchgrass steppes, cursorial spider assemblages did not undergo notable changes, except for a short-term decline in activity density on a plot with a fescue-feathergrass association (Prishutova \& Arzanov 2008). Thus, spring burning on small plots neighbouring undisturbed vegetation did not affect cursorial spider assemblages as profoundly as summer fires.

Extensive fires create more homogenous landscapes (Swengel 2001). My study shows that in the first post-fire year, cursorial spiders were distributed more evenly than in the pre-fire period. Three years after the fire, the difference between spider assemblages increased again, reflecting relief or management differences in the reserve and being more diverse than in the control unburnt gully. Pioneer generalist species did not disappear from the fire sites, but were reduced in numbers.

Litter-dependent species are the most vulnerable, as their habitat is destroyed and requires several years to recover. Such species need three 
to six or more years to recover their abundance (Panzer 2002). At the studied site, even three years after the fire, less mobile litter-dwelling spiders were found only as singletons, and these were all common grassland species. Fires are especially harmful for rare species with a patchy geographical distribution. For instance, the tertian relict Neottiura suaveolens (Krasnobayev 2001), which has only been recorded from three locations within the East European Plain, including 'Striltsivskyi Steppe', has not been reported from the study area since the fire. With an increase of fire frequency, such scarcely distributed species may disappear from the whole region. Therefore prescribed burning as a conservation management aimed at biodiversity maintenance should only be applied after the creation of adequate refuges for endangered species. Such refuges have successfully been used for Lepidoptera conservation in fire-managed areas of American prairies (Swengel \& Swengel 2007).

In general, my data are consistent with the conclusions obtained in studies of the Orenburg steppes (Nemkov \& Sapiga 2010). Steppe invertebrate communities do not recover within a three to five year period after extensive summer fires. Spider species richness did not reach the pre-fire level, as some species benefited from the fire and the community structure changed in favor of generalist and xerophilous species. It is particularly important to consider the special requirements of endangered species when planning strategies for the management of protected areas.

\section{ACKNOWLEDGEMENTS.}

The author is grateful to L. Borovyk (Luhanskyi Natural Reserve) for providing literature and vegetation description, to D. Shabanov (V. N. Karazin Kharkiv National University) for the help in data analysis, and to S. Venn (University of Helsinki) for the English proofreading and editing the manuscript.

\section{REFERENCES}

Anderson, R. C. 1990: The historic role of fire in the North American grasslands, In: Wallace, L. L. \& Collins, S. L. (eds.): Fire in tallgrass prairie ecosystems. University of Oklahoma Press, Norman, pp. 8-18.
Anderson, R. G., Leahy I. \& Dhillion S. 1989: Numbers and biomass of selected insect groups on burned and unburned sand prairie. American Midland Naturalist 122: 151-162.

Bischof, R. 2006: Faunistic-ecological studies on spiders (Araneae) in burnt areas - aspects of their significance for nature conservation. Berichte der Naturforschenden Gesellschaft Oberlausitz 14: 79-96.

Borovyk, L. P. 2012: Modern peculiarity of the steppe conservation mode in 'Streltsovsky Steppe' zapovednik. In: Ryzkov O. V. (ed.): Rezhimy osobo okhramiayemykh prirodnykh territorii. Materially mezhdunarodnoi nauchno-practicheskoi konferentsii (Kursk, 15-18 January 2012). Kursk, pp. 11-14. [in Russian, with English summary]

Chibilev, A. A. 2014: Reflections after a fire in Burtinskaya steppe. Steppe Bulletin 3: 42-43.

Cobbold S. M. \& MacMahon J. A. 2012: Guild mobility affects spider diversity: Links between foraging behavior and sensitivity to adjacent vegetation structure. Basic and Applied Ecology 13: 597-605.

Gavrilenko, V. S. 2007: Regime of absolute protection and fires in steppe reserves: unusual solution. Steppe Bulletin 23-24: 25-26. [in Russian]

Guseva N. A. \& Bogach Ya. 1988: Influence of pyrogenic factor on soil surface dwelling Coleoptera of meadow steppe. In: Structure and function of protected forest-steppe ecosystems. Moscow, pp. 56-64. [in Russian].

Hartley, M. K., Rogers, W. E., Siemann E. \& Grace J. 2007: Responses of prairie arthropod communities to fire and fertilizer: balancing plant and arthropod conservation. The American Midland Naturalist 157: 92-105.

Heidorn, R. 1991: Vegetation management guideline: exotic buckthorns: common buckthorn (Rhamnus cathartica L.), glossy buckthorn ( $R$. frangula L.) and Duhurian buckthorn (R. davurica Pall.). Natural Areas Journal 11: 216-217.

Horvath, R., Magura, T., Szinetar, Č. \& Tothmeresz, B. 2009: Spiders are not less diverse in small and isolated grasslands, but less diverse in overgrazed grasslands: A field study (East Hungary, Nyirseg). Agriculture, Ecosystems and Environment 130: 16-22.

Ysnel F. \& Canard A. 2000: Spider biodiversity in connection with the vegetation structure and the foliage orientation of hedges. Journal of Arachnology 28: 107-114. 
Kahmen, S., Poschlod P. \& Schreiberb K.-F. 2002: Conservation management of calcareous grasslands. Changes in plant species composition and response of functional traits during 25 years. Biological Conservation 104: 319-328.

Krasnobayev, Y. P. 2001: Zoogeogrphical analysis of the araneofauna of the Samarskaya Luka. Zoological Journal 80: 1315-1320. [in Russian, with English summary]

Krasnobayev, Y. P. 2003: Structure of herpetobiont and hortobiont spider populations in Samarskaya Luka. Izvestia Samarskogo Nauchnogo Tsentra Rossiyskoi Akademii Nauk. Spetsialnyi Vypusk, 1: 147-156. [in Russian].

Lysenko, H. M. 2008: Pyrogenic aspects of the abiotic regulation of steppe reserve ecosystems. Ekolohia ta Noospherolohia. 19: 143147 [in Russian, with English summary].

Magurran, A. E. 1991: Ecological diversity and its measurements. Chapman and Hall, London, $178 \mathrm{pp}$.

Nemkov V. A. \& Sapiga E. V. 2010: Impact of fires on the fauna of terrestrial arthropods in protected steppe ecosystems. Russian Journal of Ecology 41: 173-179.

Nekola J. C. 2002: Effects of fire management on the richness and abundance of central North American grassland land snail faunas. Animal Biodiversity and Conservation 25: 53-66.

Oparin, M. L. \& Oparina O. S. 2003: Impact of fire on the dynamics of steppe vegetation. Povolzhskiy Journal of Ecology 2: 158-171. [in Russian, with English summary]

Osychnyuk, V. V. \& Istomina G. G. 1970: Influence of burning on steppe vegetation. Ukrainian Botanical Journal 27: 284-290. [in Ukrainian, with English summary]

Page, H. \& Goldammer, J. G. 2004: Prescribed burning in landscape management and nature conservation: The first long-term pilot project in Germany in the Kaiserstuhl viticulture area, Baden-Württemberg, Germany. International Forest Fire News 30: 49-58.

Panzer, R. 2002: Compatibility of prescribed burning with the conservation of insects in small, isolated prairie reserves. Conservation Biology 16: 1296-1307.

Parmenter, R. R. 2008: Long-term effects of a summer fire on desert grassland plant demographics in New Mexico. Rangeland Ecological \& Management 61: 156-168.

Pichka, V. E. 1984: To the spider fauna of the Central-Chernozyom Reserve. In: Fauna i ekologi- ya paukoobrasnykh. Perm University, Perm pp. 68-77. [in Russian]

Polchaninova, N. Y. 1990: Comparative characteristics of the spider fauna of the steppes of Left-bank Ukraine In: News of faunistics and systematic. In: I. A. Akimov (ed.): In-t zool. AN Ukr SSR, Kiev, pp. 163- 167. [in Russian,]]

Polchaninova, N. Y. 1995. Araneofauna of the «Streltsovkaya Steppe» (Lugansk Area) and its place in the fauna of protected steppe territories In: Problemy sokhranenya raznoobraziya prirodnykh stepnykh i lesostepnykh regionov Materialy Rossiysko-Ukrainskoi nauchnoi konferentsii (pos. Zapovednoye Kurskoi oblasti, 22-27 May 1995). KMK Scientific Press, Moscow, pp. 185-186. [in Russian].

Polchaninova, N. Y. 2002: Fauna and assemblages of spiders (Aranei) of the Yamskaya Steppe Reserve (Belgotod Area, Russia). Kharkov Entomological Society Gazette 10: 45-51. [in Russian with English summary]

Polchaninova, N. Y. 2003: Effect of hay-mowing on spider communities of the meadow steppes of the Central forest-steppe (Russia and Ukraine). Arthropoda Selecta (Special Issue 1).: 261-273.

Polchaninova, N. Y. 2006: Materials to the spider fauna inventory (Araneae) of the 'Khomutovskaya steppe' Nature Reserve (Donetsk Area). The Journal of V. N. Karazin Kharkiv National University, Series Biology, 729: 1-9 [in Russian, with English summary].

Polchaninova, N. Y. 2012: Assemblages of herbdwelling spiders (Araneae) of various steppe types in Ukraine and the Central Chernozem region of Russia. Arachnologische Mitteilungen 43: 66-67.

Polchaninova, N. Y. \& Prokopenko, E. V. 2013: Catalogue of the spiders (Arachnida, Aranei) of Left-Bank Ukraine. Arthropoda Selecta (Supplement 2): 1-268.

Ponomarev, A. V. \& Tsvetkov A. S. 2004: Summarized data on the spiders (Aranei) of the 'Rostovskiy' Reserve. Trudy Gosudarstvennogo Prirodnogo Zapovednika 'Rostovskiy' Vypusk 3: 84-104. [in Russian, with English summary].

Ponomarev, A. V. \& Polchaninova, N. Y. 2006: The materials on the fauna of spiders (Aranei) of Belgorod Area. Caucasian Entomological Bulletin 2: 143-156. [in Russian, with English summary]. 
Prishutova, Z. G. \& Arzanov, Y. G. 2008: Influence of the local steppe fire on the gerpetobionts. Trudy Gosudarstvennogo Prirodnogo Zapovednika 'Rostovskiy' Vypusk 4: 192-208. [in Russian, with English summary].

Prokopenko, E. V. 2001a. The spider fauna of the Lugansk Nature Reserve. In: Bioriznomanittia pryrodnykh i tekhnohennykh biotopiv Ukrainy. In: Materialy Vseukrainskoi konferentsii studentiv, aspirantiv i molodykh vchenykh. Ch. 2. Donetsk, DonNU, pp. 160164 [in Russian].

Prokopenko E. V. 2001b. Spiders (Aranei) of natural and transformed landscapes of the southeast of Ukraine (fauna and ecology). Autoreferate of the Thesis of Candidate (Ph.D.) of Biological Sci. Degree. Institute of Zoology of UAS, Kyiv, 20 pp. [in Russian, with English summary].

Prokopenko E. V. \& Savchenko, E. Y. 2013: An influence of the steppe fire on fauna and spiders population structure (Aranei, Arachnida) in «Kamennye Mogyly» reserve (Volodarskiy Region, Donetskaya Oblast) Biological Bulletin of Bogdan Chmelnitskiy Melitopol State Pedagogical University 1: 90-105. [in Russian, with English summary].

Robertson, K. R., Anderson, R. C. \& Schwartz M. W. 1997: The tallgrass prairie mosaic. In: Schwartz, M. W. (ed.): Conservation in highly fragmented landscapes. Chapman and Hall, New York, pp. 55-87.

Rook, E. J., Fischer, D. G., Seyferth, R. D., Kirsch, J. L., LeRoy, C. J. \& Hamman, S. 2011: Responses of prairie vegetation to fire, herbicide, and invasive species. Legacy Northwest Science 85: 288-302.

Ryabtsov, S. N. 2005: Impact of burning pressure on the vegetation cover of the South Cisurals steppe. Thesis of Candidate (Ph.D.) of Biological Sci. Degree. Orenburg, 203 pp.

Samu, F., Kádár, F., Ónodi, G., Kertész, M., Szirányi, A., Szita, É., Fetykó, K., Neidert, D., Botos, E. \& Altbäcker V. 2010: Differential ecological responses of two generalist arthropod groups, spiders and carabid beetles (Araneae, Carabidae), to the effects of wildfire. Community Ecology 11: 129-139.

Savchenko K. Y. 2009: Pyrogenic factor influence on surface-dwelling Coleoptera in the forbsfescue-feather grass steppe. Kharkov Entomological Society Gazette 17(1-2): 67-73 [in Russian, with English summary]
Swengel, A. B. 2001: A literature review of insect responses to fire, compared to other conservation managements of open habitat. Biodiversity Conservation 10: 1141-1169.

Swengel, A. B. \& Swengel, S. R. 2007: Benefit of permanent non-fire refugia for Lepidoptera conservation in fire-managed sites. Journal of Insect Conservation 11: 263-279.

Tischler, W. 1949: Grundzüge der terrestrischen Tierökologie. Braunschweig, Veiweg, 219 pp.

Tishkov, A. A. 2003: Fires in steppes and savannahs. In: Materials of the $3^{\text {rd }}$ International Symposium 'Steppes of Northern Eurasia'. Gazprompechat, Ornburg, pp. 9-22 [in Russian].

Tkachenko, V. S. 2009: 'Striltsivskyi Steppe' in phytocoenotic monitoring of Starobilsk steppes. News of Biosphere Reserve 'Askania-Nova' 11: 6-19. [in Ukrainian, with English summary].

Tkachenko, V. S., Sirenko, V. O. \& Podpriatov O. O. 2010: Steppe fire and pyrogenic experiment in "Kamyani Mohyly" (Donetsk Region). News of Biosphere Reserve 'AskaniaNova' 12: 5-20. [In Ukrainian with English summary].

Vale, T. R. 2002: Fire, native peoples, and the natural landscape. Island Press, Washington DC., $336 \mathrm{pp}$

Valkó, O., Török, P., Deák, B. \& Tóthmérész, B. 2013: Review: Prospects and limitations of prescribed burning as a management tool in European grasslands. Basic and Applied Ecology 15: 26-33

Warren, S. D., Scifres, C. J. \& Teel, P. D. 1987: Response of grassland arthropods to burning: a review. Agricalture, Ecosystems, Environment 19: 103-130.

Weyman, G. S. 1993: A review of the possible causative factors and significance of ballooning in spiders. Ethology, Ecology and Evolution 5: 279-291. 


\section{APPENDIX}

Spider species recorded from the 'Striltsivskyi Steppe' Nature Reserve and its vicinity before and after the fire of 2008.

\begin{tabular}{|c|c|c|c|c|c|}
\hline \multirow{2}{*}{ Species } & \multicolumn{3}{|c|}{ 'Striltsivskyi Steppe' } & \multicolumn{2}{|c|}{ Control gully } \\
\hline & 1984-2000 & 2009 & 2011 & 2009 & 2011 \\
\hline \multicolumn{6}{|l|}{ Family Atypidae } \\
\hline Atypus muralis Bertkau, 1890 & + & r & + & + & + \\
\hline \multicolumn{6}{|l|}{ Family Eresidae } \\
\hline Eresus kollari Rossi, 1846 & . & . & + & . & + \\
\hline \multicolumn{6}{|l|}{ Family Theridiidae } \\
\hline Asagena phalerata (Panzer, 1801) & + & . & + & + & + \\
\hline Crustulina guttata (Wider, 1834) & + & . & . & . & \\
\hline Enoplognatha ovata (Clerck, 1757) & + & . & . & . & + \\
\hline E. thoracica (Hahn, 1833) & + & . & + & . & \\
\hline Euryopis quinqueguttata Thorell, 1875 & . & . & . & . & + \\
\hline E. saukea Levi, 1951 & . & . & + & . & . \\
\hline Heterotheridion nigrovariegatum (Simon, 1873) & + & . & . & . & . \\
\hline Neottiura bimaculata (Linnaeus, 1767) & + & . & + & + & . \\
\hline N. suaveolens (Simon, 1879) & + & . & . & . & . \\
\hline Phylloneta impressa (L. Koch, 1881) & + & + & + & + & + \\
\hline Robertus heydemanni Wiehle, 1965 & + & . & . & . & . \\
\hline Simitidion simile (C. L. Koch, 1836) & + & . & . & + & + \\
\hline Steatoda albomaculata (De Geer, 1778) & . & + & . & . & . \\
\hline Theridion innocuum Thorell, 1875 & + & . & . & . & . \\
\hline \multicolumn{6}{|l|}{ Family Linyphiidae } \\
\hline Agyneta rurestris (C. L. Koch, 1836) & + & . & . & + & + \\
\hline A. simplicitarsis (Simon, 1884) & + & . & . & + & + \\
\hline Dactylopisthes mirificus (Georgescu, 1976) & + & . & . & . & . \\
\hline Linyphia triangularis (Clerck, 1757) & + & + & + & + & + \\
\hline Maso sundevalli (Westring, 1851) & + & . & . & . & . \\
\hline Microlinyphia pusilla (Sundevall, 1830) & + & . & . & . & + \\
\hline Minicia caspiana Tanasevitch, 1990 & + & . & . & . & + \\
\hline Oedothorax apicatus (Blackwall, 1850) & + & . & . & . & . \\
\hline Pocadicnemis pumila (Blackwall, 1841) & . & . & . & + & . \\
\hline Porrhomma convexum (Westring, 1851) & + & . & . & . & . \\
\hline Stemonyphantes lineatus (Linnaeus, 1758) & + & . & + & + & + \\
\hline Trichoncus vasconicus Denis, 1944 & + & . & + & + & \\
\hline Uralophantes troitskensis Esyunin, 1992 & . & . & . & . & + \\
\hline \multicolumn{6}{|l|}{ Family Tetragnathidae } \\
\hline Metellina segmentata (Clerck, 1757) & + & . & . & . & . \\
\hline Pachygnatha degeeri Sundevall, 1830 & + & . & + & + & . \\
\hline \multicolumn{6}{|l|}{ Family Araneidae } \\
\hline Aglenatea redii (Scopoli, 1763) & + & . & + & + & + \\
\hline Araneus quadratus Clerck, 1757 & + & + & + & + & . \\
\hline Araniella cucurbitina (Clerck, 1757) & + & . & . & . & . \\
\hline Argiope bruennichi (Scopoli, 1772) & + & + & + & + & + \\
\hline
\end{tabular}




\begin{tabular}{|c|c|c|c|c|c|}
\hline \multirow{2}{*}{ Species } & \multicolumn{3}{|c|}{ 'Striltsivskyi Steppe' } & \multicolumn{2}{|c|}{ Control gully } \\
\hline & $1984-2000$ & 2009 & 2011 & 2009 & 2011 \\
\hline Cercidia prominens (Westring, 1851) & + & + & + & + & + \\
\hline Cyclosa oculata (Walckenaer, 1802) & . & . & . & + & . \\
\hline Hypsosinga sanguinea (C. L. Koch, 1844) & + & . & . & . & + \\
\hline Mangora acalypha (Walckenaer, 1802) & + & . & + & + & + \\
\hline Neoscona adianta (Walckenaer, 1802) & + & . & + & + & + \\
\hline Singa hamata (Clerck, 1757) & + & . & + & + & + \\
\hline \multicolumn{6}{|l|}{ Family Lycosidae } \\
\hline Alopecosa accentuata (Latreille, 1817) & . & . & + & . & . \\
\hline A. cuneata (Clerck, 1757) & + & + & + & + & + \\
\hline A. cursor (Hahn, 1831) & + & + & + & + & + \\
\hline A. pulverulenta (Clerck, 1757) & + & + & + & + & + \\
\hline A. schmidti (Hahn, 1835) & + & . & . & . & + \\
\hline A. solitaria (Herman, 1879) & + & . & + & . & + \\
\hline A. sulzeri (Pavesi, 1873) & + & + & + & + & + \\
\hline A. taeniopus (Kulczynski, 1895) & + & . & + & + & + \\
\hline A. trabalis (Clerck, 1757) & . & . & . & + & . \\
\hline Lycosa singoriensis (Laxmann, 1770) & + & . & . & . & . \\
\hline Pardosa agrestis (Westring, 1861) & + & + & + & . & + \\
\hline P. lugubris (Walckenaer, 1802) & + & . & + & + & + \\
\hline P. paludicola (Clerck, 1757) & + & . & + & . & . \\
\hline P. palustris (Linnaeus, 1758) & . & . & + & . & . \\
\hline P. prativaga (L. Koch, 1870) & + & + & + & . & + \\
\hline Trochosa robusta (Simon, 1876) & + & + & + & + & + \\
\hline T. ruricola (De Geer, 1778) & + & . & . & . & . \\
\hline T. terricola Thorell, 1856 & + & + & + & + & + \\
\hline Xerolycosa miniata (C.L. Koch, 1834) & + & + & + & + & + \\
\hline \multicolumn{6}{|l|}{ Family Pisauridae } \\
\hline Pisaura novicia (L. Koch, 1878) & + & . & + & . & + \\
\hline \multicolumn{6}{|l|}{ Family Oxyopidae } \\
\hline Oxyopes heterophthalmus (Latreille, 1804) & . & . & + & + & . \\
\hline \multicolumn{6}{|l|}{ Family Miturgidae } \\
\hline Zora pardalis Simon, 1878 & + & . & + & + & + \\
\hline Z. spinimana (Sundevall, 1833) & . & . & . & + & . \\
\hline \multicolumn{6}{|l|}{ Family Dictynidae } \\
\hline Dictyna arundinacea (Linnaeus, 1758) & + & . & + & + & + \\
\hline D. latens (Fabricus, 1775) & + & . & + & . & + \\
\hline D. uncinata Thorell, 1856 & . & . & . & + & . \\
\hline \multicolumn{6}{|l|}{ Family Titanoecidae } \\
\hline Titanoeca schineri L. Koch, 1872 & + & . & . & . & . \\
\hline \multicolumn{6}{|l|}{ Family Eutrichuridae } \\
\hline Cheiracanthium erraticum (Walckenaer, 1802) & + & . & . & + & . \\
\hline C. pennyi O. Pickard-Cambridge, 1873 & + & . & + & + & + \\
\hline C. punctorium (Villers, 1789) & + & + & + & + & + \\
\hline C. virescens (Sundevall, 1832) & + & . & . & . & . \\
\hline \multicolumn{6}{|l|}{ Family Liocranidae } \\
\hline Agroeca cuprea Menge, 1873 & + & + & + & + & + \\
\hline A. maculata C. Koch, 1879 & . & . & + & + & . \\
\hline
\end{tabular}




\begin{tabular}{l}
\hline Species \\
\hline Family Clubionidae \\
Clubiona frutetorum L. Koch, 1867 \\
C. lutescens Westring, 1851 \\
C. neglecta O. Pickard-Cambridge, 1862 \\
C. pseudoneglecta Wunderlich, 1994 \\
C. subtilis L. Koch, 1867
\end{tabular}

\section{Family Phrurolithidae}

Phrurolithus festivus (C. L. Koch, 1835)

P. pullatus Kulczyn'ski, 1897

\section{Family Gnaphosidae}

Berlandina cinerea (Menge, 1872)

Callilepis nocturna (Linnaeus, 1758)

Drassodes pubescens (Thorell, 1856)

Drassyllus praeficus (L. Koch, 1866)

D. pusillus (C. L. Koch, 1833)

Gnaphosa leporina (L. Koch, 1866)

G. licenti Schenkel, 1953

G. lugubris (C. L. Koch, 1839)

G. taurica Thorell, 1875

Haplodrassus dalmatensis (L. Koch, 1866)

H. kulczynskii Lohmander, 1942

H. signifer (C. L. Koch, 1839)

H. umbratilis (L. Koch, 1866)

Micaria dives (Lucas, 1846)

M. formicaria (Sundevall, 1831)

M. fulgens (Walckenaer, 1802)

M. pilicaria (Sundevall, 1831)

Poecilochroa variana (C. L. Koch, 1839)

Trachyzelotes malckini Platnik \& Murphy, 1984

Zelotes electus (C. L. Koch, 1839)

Z. fuscus (Thorell, 1875)

Z. latreillei (Simon, 1878)

Z. longipes (L. Koch, 1866)

Z. pseudogallicus Ponomarev, 2007

\section{Family Sparassidae}

Micrommata roseum (Clerck, 1757)

\section{Family Philodromidae}

Philodromus cespitum (Walckenaer, 1802)

P. histrio (Latreille, 1819)

Thanatus arenarius L. Koch, 1872

Tibellus macellus Simon, 1875

T. oblongus (Walckenaer, 1802)

\section{Family Thomisidae}

Ebrechtella tricuspidata (Fabricius, 1775)

Heriaeus oblongus Simon, 1918

Misumena vatia (Clerck, 1757)

Ozyptila atomaria (Fabricius, 1775)

\section{'Striltsivskyi Steppe'}

1984-2000 2009

2011

Control gully

2009

2011$$
+
$$$$
+
$$$$
+
$$$$
+
$$

. 


\begin{tabular}{|c|c|c|c|c|c|}
\hline \multirow{2}{*}{ Species } & \multicolumn{3}{|c|}{ 'Striltsivskyi Steppe' } & \multicolumn{2}{|c|}{ Control gully } \\
\hline & 1984-2000 & 2009 & 2011 & 2009 & 2011 \\
\hline O. praticola (C. L. Koch, 1837) & . & . & . & + & . \\
\hline O. scabricula (Westring, 1851) & + & . & + & + & + \\
\hline Thomisus onustus Walckenaer, 1805 & + & . & + & + & + \\
\hline Tmarus piger (Walckenaer, 1802) & . & + & . & . & + \\
\hline Xysticus acerbus Thorell, 1872 & + & . & . & . & . \\
\hline X. cristatus (Clerck, 1758) & + & + & + & + & + \\
\hline X. kochi Thorell, 1872 & + & + & + & + & + \\
\hline X. laetus Thorell, 1875 & + & . & + & . & . \\
\hline X. lanio C. L. Koch, 1835 & + & . & . & . & . \\
\hline X. luctuosus (Blackwall, 1836) & + & . & . & . & . \\
\hline X. ninnii Thorell, 1872 & . & . & . & + & . \\
\hline X. striatipes L. Koch, 1870 & + & + & + & + & + \\
\hline X. ulmi (Hahn, 1831) & + & + & . & . & + \\
\hline \multicolumn{6}{|l|}{ Family Salticidae } \\
\hline Aelurillus laniger Logunov \& Marusik, 2000 & . & . & + & . & . \\
\hline A. v-insignitus (Clerck, 1757) & . & + & + & . & . \\
\hline Asianellus festivus (C. L. Koch, 1834) & + & . & . & . & . \\
\hline Carrhotus xanthogramma (Latreille, 1819) & + & . & . & + & . \\
\hline Chalcoscirtus nigritus (Thorell, 1875) & + & . & . & . & . \\
\hline Euophrys frontalis (Walckenaer, 1802) & + & + & + & + & . \\
\hline Evarcha arcuata (Clerck, 1757) & + & . & + & + & + \\
\hline E. falcata (Clerck, 1757) & + & + & + & + & . \\
\hline E. laetabunda (C. L. Koch, 1846) & + & . & . & . & . \\
\hline Evarcha michailovi Logunov, 1992 & + & + & + & + & + \\
\hline Heliophanus auratus C.L. Koch, 1835 & + & . & . & . & . \\
\hline H. cupreus (Walckenaer, 1802) & + & . & . & . & . \\
\hline H. flavipes (Hahn, 1832) & + & . & + & + & . \\
\hline Neon rayi (Simon, 1875) & + & . & . & . & . \\
\hline Myrmarachne formicaria (De Geer, 1778) & + & . & + & + & . \\
\hline Philaeus chrysops (Poda, 1761) & + & + & + & + & + \\
\hline Phlegra fasciata (Hahn, 1826) & + & + & + & . & . \\
\hline Sitticus dzieduszyckii (L. Koch, 1870) & + & . & . & . & . \\
\hline Synageles hylarulus (C.L. Koch, 1846) & + & . & . & + & . \\
\hline S, subcingulatus Simon, 1878 & + & . & + & + & + \\
\hline Talavera aequipes (O. Pickard-Cambridge, 1871) & + & . & . & . & . \\
\hline Total number of species & 117 & 40 & 89 & 77 & 72 \\
\hline
\end{tabular}

